Ethiopian Journal of Environmental Studies \& Management 7(2): 153 - 159, 2014.

ISSN:1998-0507

doi: http://dx.doi.org/10.4314/ejesm.v7i2.6

Submitted: November 1, 2013

Accepted: February 28, 2014

\title{
ASSESSMENT OF MICROBIOLOGICAL AND PHYSICOCHEMICAL PARAMETERS OF GROUND WATER: A CASE STUDY OF GIKONDO INDUSTRIAL PARK, KIGALI, RWANDA
}

\author{
RUTANGA, J.P. \\ Applied Biology Department, Science faculty of Kigali Institute of Science and Technology (KIST), \\ B.P 3900 Kigali-Rwanda \\ Email: jeanrutanga@yahoo.fr
}

\begin{abstract}
The main objective of our study was to determine the physicochemical and microbiological characteristics of two water samples: river and ground water, in Gikondo industrial park, compared to the tap water. Samples were collected from the main three sources: industrial park effluent water (river water), industrial spring water and tap water. The physicochemical properties were assessed and recorded as $\mathrm{pH}$ (6.9-7.75, 6.00-6.20 and 6.01-6.3 for river, spring and tap water respectively), turbidity (42-92.0, 8.9-9.1 and 12.3-14.1 for river, spring and tap water respectively), chloride (Cl-) (7.1-10.5, 9.5-12.5 and 1.8-2.8 for river, spring and tap water respectively), thiocyanide (SCN-) (++++; +++; +), chemical oxygen demand (COD) (5.0-8.9, 7.4-9.6 and 11.5-13.9 for river, spring and tap water respectively), biological oxygen demand (BOD) (0.60-0.75, 1.20-1.67 and 21.24-24.73 for river, spring and tap water respectively) and dissolved oxygen $D O(0.90-0.98,1.9-2.3$ and 32-34 for river, spring and tap water respectively). Microbial analysis was conducted based on different indicators such as gas formation by catalase activity, MR/VP test and Indole formation test. In all, the microbial analysis resulted in the presence of Klebsiella, Enterobacter, Staphylococcus and Escherichia coli in the industrial river water (river water), which showed a maximum pollution rate compared to the other two samples. Such results will definitely have a key role to ascertain the impact of the industrial effluent on Gikondo industrial Park area and any potential harmful and hazardous effects on aquatic organisms, humans and plants within that environment.
\end{abstract}

Key Words: Industrial effluent, Gikondo industrial park, physicochemical properties, microbiological analysis, water analysis.

Introduction

Water is one of the most important wildlife habitats. The water provides environment to fish, plants and animals. There are several sources of water pollution which work together to influence the overall quality of the river water. The commonly cited sources of water pollutants are the industries, municipal wastes, domestic wastes and agrochemicals and other industrial discharge products. There is also run-off of rain water from drains and other waste leakages from urban areas that contribute to contamination of the main river supplies. As a result, the net activities mentioned above add up to the various pollutants such as organic and inorganic chemicals and toxic heavy metals that find their ways to the river water system (Sial et al., 2006; Pelczar et al., 1986).

In Rwanda, many industries are found in Kigali city. A large number of these industries are located in Gikondo area. The major ones are textile, sugar, chemical processing, chemicals, and food processing industries, battery, cement, milling and leather tanning manufacturing industries. The major industries located in Gikondo area are construction, food processing and heavy metals processing industries. These industries have developed their waste effluent without a proper pretreatment system. These discharges or effluents in the nearby natural drains, ultimately surface into the water of Nyabugogo River.

The effluents discharged by different industries contain a high range of constituents that affect the chemical and physical parameters of water that include: temperature, $\mathrm{pH}$, conductivity, hardness, alkalinity, biological oxygen demand (BOD), chemical oxygen demand (COD), dissolved oxygen (DO), total soluble salts (TSS), nitrates, nitrites, natural cations $\left(\mathrm{Na}^{+}, \mathrm{K}^{+}, \mathrm{Ca}^{2+}\right.$ and $\left.\mathrm{Mg}^{2+}\right)$, anions $\left(\mathrm{Cl}^{-}, \mathrm{CO}_{3}{ }^{2-}, \mathrm{HCO}_{3}{ }^{-}, \mathrm{SO}_{4}{ }^{2-}\right)$ and to some degree heavy metals such as chromium, cadmium, copper, lead, nickel, zinc, cobalt, magnesium, iron and arsenic (Perrin and Scharff, 2002). 
Many industries and factories in Kigali city, Rwanda, don't have proper disposal means of their wastes (solid and liquids); hence the wastes easily find their way into nearby streams which eventually trickle towards Nyabugogo River. Therefore, there is Variability in the quality of the river water due to industrial effluents which also vary with the respective industrial processes. In addition to the industries, the municipal sewage also finds its way into the Nyabugogo River possibly compounding the eutrophication. There is a need to monitor, evaluate and determine the possibility of the existence of pollutants and their levels from such regularly used water sources for national budget and planning purposes because of a potential outbreak of diseases.

This study was conducted to determine the chemical, physical and micriological quality of Gikondo industrial effluent, industrial area spring and tap water. Water from Gikondo industrial effluents is used for several human activities that include fishing and as source of water for other household purposes. Therefore, it is imperative that we are better informed of the microbial and chemical composite of such water sources because these components are of health concern.

The analysis of chemical pollutants present in water along Nyabugogo River, reveals how the aquatic organism live on that polluted water and provide adequate information about quality of water for the assessment and monitoring technique.

The main objective of our study was to determine the potential chemical and microbiological hazards associated with water discharged with Gikondo industrial effluents that may cause pollution of Nyabugogo River. The specific objectives were: To determine the physicochemical properties of Nyabugogo river, to characterise the toxic chemical compounds present in the river, to assess the possible pollutants of chemical in nature from the industrial area along Nyabugogo river and identify the microbial properties of Gikondo industrial effluents as bio-indicators of eutrophication.

\section{Material and Methods Study Area}

In Rwanda, many industries are found in Kigali city. A large number of these industries are located in Gikondo area. The major ones are textile, sugar, chemical processing, chemicals, and food processing industries, battery, cement, milling and leather tanning manufacturing industries. The major industries located in Gikondo are construction industries, food processing industry and heavy metals processing industry. These industries produce their waste effluent without a proper pretreatment system. These discharges or effluents in the nearby natural drains, ultimately surface into the Nyabugogo River.

\section{Sampling}

A total of nine samples were collected in three different days. Three samples from each site of the discharge outlets points of different industrial units (construction industries, food processing industry and heavy metals processing industry), spring water and normal tap water from Gikondo industrial area were collected and brought to the Kigali Institute of Science and Technology (KIST) laboratory for various physicochemical and microbiological parameters analysis.

Analysis was carried out in three times, in different days. Tests that were performed for water quality include chemical and physical tests: $\mathrm{P}^{\mathrm{H}}$, turbidity, chemical oxygen demand (COD), biological oxygen demand (BOD), dissolved oxygen (DO), chloride $\left(\mathrm{Cl}^{-}\right)$and thiocyanate $\left(\mathrm{SCN}^{-}\right)$. During microbial tests, Klebsiella, Enterobacter, Staphylococcus and Escherichia coli were examined. The overall obtained results for both chemical and physical tests were compared with those of world health organization (WHO) for drinking water quality.

\section{Physicochemical analysis \\ Procedure for chloride determination by silver nitrate titration}

1) $50 \mathrm{ml}$ of sample was measured into Erlenmeyer flask. Since silver and hexavalent chromium are both heavy metals, a few $\mathrm{ml}$ of sample was used. Then, 5-6 drops of potassium chromate were added to indicate solution.

2) The mixture was stirred using a magnetic stirrer.

3) The burette was filled with the standard silver nitrate solution.

4) Silver nitrate titrant was added until yellow color just turns from yellow or cloudy yellow and the titration was continued until orange color first appeared.

5) A few seconds were counted to check whether the orange color persists. If it did, the final reading was recorded from the burette.

6) The $50 \mathrm{ml}$ of sample used was entered as well as the initial and final burette readings into 
Quattro Pro spreadsheet to have final concentration of chloride calculated.

\section{Procedure for Chemical Oxygen Demand (COD)}

1) Graduated cylinder and Erlenmeyer flask were rinsed twice with sample water and volume of $100 \mathrm{ml}$ sample was measured into the flask.

2) $10 \mathrm{ml}$ of sulfuric acid were added into flask and swirl to mix.

3) Solution was put in hot plate for boiling.

4) After boiling, the solution was removed from the hot plate.

5) The burette was filled with potassium permanganate and for any air bubbles expressed in the tip was removed with the same solution. The burette was set at zero.

6) The flask was placed below the burette tip and $10 \mathrm{ml}$ of potassium permanganate was added. Solution turns from colorless to pink.

7) The solution was put back on hot plate and boiled exactly for ten minute.

8) Another burette was filled with oxalic acid and any air bubbles from the tip were removed. The burette was set at zero.

9) The solution was removed from the hot plate and the flask was placed below the burette tip and $10 \mathrm{ml}$ of oxalic acid was added. Solution turned from pink to colorless.

10) The flask was removed quickly and placed then below the burette tip of potassium permanganate; potassium permanganate was added slowly until the solution become slightly pink. The first drop that turns the solution from colorless to pink was considered as the endpoint of the titration. The result was expressed in $\mathrm{ml} / \mathrm{g}$.

\section{Inorganic qualitative analysis}

These analytical techniques makes use of a systematic scheme to confirm the presence of certain, usually aqueous, ions or elements by performing a series of reactions that eliminate ranges of possibilities and then confirms suspected ions with a confirming test. Sometimes small carbon containing ions are included in such schemes like Cyanate $\left(\mathrm{OCN}^{-}\right)$, Thiocyanate $\left(\mathrm{SCN}^{-}\right)$, Cyanide $\left(\mathrm{CN}^{-}\right)$(Skoog et al., 1988).

For qualitative analysis of $\mathrm{SCN}^{-}$, The equilibrium reaction between iron chloride $\left(\mathrm{FeCl}_{3}\right)$ and sodium thiocyanate $(\mathrm{NaSCN})$ that was showed the presence of thiocyanate ions $\left(\mathrm{SCN}^{-}\right)$in water. This method of qualitative analysis showed only if the test ions were presents or not. Once the iron chloride was orange and the sodium thiocyanate was colorless, together they yielded a red blood salt precipitate of iron thiocyanate solution and that color of precipitate indicates the presence of thiocyanate ions.

\section{Undilution method of BOD and $\mathrm{DO}$}

An excess amount of $\mathrm{Na}_{2} \mathrm{SO}_{3}$ was added to a particular amount of sampled water that has been oxidized by $\mathrm{Na}_{2} \mathrm{SO}_{3}$ to $\mathrm{Na}_{2} \mathrm{SO}_{4}$, before the dissolved oxygen is measured using inoLab Oxi 730. The sample was kept at $20^{\circ} \mathrm{C}$ in the dark to prevent photosynthesis for five days, and the dissolved oxygen was measured again. After the required incubation time, the concentration of unabsorbed $\mathrm{Na}_{2} \mathrm{SO}_{3}$ was determined by an inoLab Oxi 730. Difference in concentration of $\mathrm{Na}_{2} \mathrm{SO}_{3}$ would give rise to an amount of dissolved oxygen consumed by the sampled water, i.e. the difference between the final DO and initial DO was the BOD (Mark et al., 1996).

\section{Microbiological analysis}

Procedure of catalase test: Testing on agar slope.

1) Sampled water was cultured for 24 hours on a nutrient agar slope.

2) $1 \mathrm{ml}$ hydrogen peroxide solution $(10 \mathrm{ml})$ was carefully poured onto the slope.

3) Vigorous production of gas bubble was an indication of a positive test.

\section{Procedure of indole test}

1) Benzaldehyde was dissolved in the amyl alcohol in $50^{\circ} \mathrm{C}$. Then the acid was carefully added. By the time the reagent turned red, it was placed in the refrigerator at $4^{\circ} \mathrm{C}$ until color changed to golden yellow and stored in a brown bottle or a bottle covered in aluminum foil.

2) The tryptophan (or peptone) broth was inoculated with the test organism and incubated at $37^{\circ} \mathrm{C}$ for $24-28$ hours.

3) $0.5 \mathrm{ml}$ of the Kovac's reagent was added and gently agitated.

4) The upper layer of the liquid was examined to test the accuracy of the results which show a dark pink color (confirming the presence of E. coli).

Procedure of methyl red-voges proskauer (MR/VP test)

1) The VP medium and $1 \mathrm{ml}$ of distilled water were placed into a test tube.

2) Inoculation was heavily performed with either 2-3 drops of heavy suspension of the organism to be tested or with a heavy loop full of organism directly from the place.

3) Incubation at $37^{\circ} \mathrm{C}$ was continued for $6-8$ hours, but no more than 8 hours.

4) After incubation, 3 drops of $40 \mathrm{KOH}$ were added and mixed by gently shaking.

5) the two drops alpha-napthol reagent was added and a reagent would form a thin layer on the surface of the liquid. 
6) The tube was allowed to stand, up to 30 minutes, observing periodically for the appearance of a pink-burgundy color (confirming the presence of Klebsiella and Enterobacter).

\section{Results and Discussion \\ Physico-chemical Analysis}

Table 1: Physico-chemical analysis of the three effluents found in Gikondo industrial park

\begin{tabular}{|c|c|c|c|c|c|c|c|}
\hline \multicolumn{8}{|c|}{ Day 1 (10 ${ }^{\text {th }}$ April, 2012) } \\
\hline Type of Sample & $\mathrm{pH}$ & NTU & $\mathrm{CL}^{-}$ & $\mathrm{SCN}^{-}$ & COD & BOD & $\mathrm{DO}$ \\
\hline River Water & 7.75 & 90.5 & 7.1 & ++++ & 5.5 & 0.65 & 0.93 \\
\hline Spring Water & 6.2 & 8.7 & 9.4 & +++ & 8.5 & 1.35 & 1.9 \\
\hline Tap Water & 6.01 & 14.1 & 1.8 & + & 11.5 & 21.24 & 33.02 \\
\hline \multicolumn{8}{|c|}{ Day $2\left(24^{\text {th }}\right.$ April, 2012) } \\
\hline River Water & 7.56 & 92.0 & 7.9 & ++++ & 5.0 & 0.60 & 0.90 \\
\hline Spring Water & 6.0 & 8.9 & 10.3 & ++ & 7.4 & 1.2 & 2.1 \\
\hline Tap Water & 6.1 & 13.3 & 2.1 & + & 12.9 & 22.60 & 32 \\
\hline \multicolumn{8}{|c|}{ Day 3 ( $8^{\text {th }}$ May, 2012) } \\
\hline River Water & 6.9 & 42 & 10.5 & +++++ & 8.9 & 0.75 & 0.98 \\
\hline Spring Water & 6.02 & 9.1 & 12.5 & +++ & 9.6 & 1.67 & 2.3 \\
\hline Tap Water & 6.3 & 12.3 & 2.8 & ++ & 13.9 & 24.73 & 34 \\
\hline
\end{tabular}

The general physicochemical analyses of the river, spring water and tap water are given in Table 1. The $\mathrm{pH}$ values of river water were alkaline, whereas the ones for both spring and tap water were acidic. Among the three collected samples, river water shows a slightly high $\mathrm{pH}$ value of 6.9-7.75. The $\mathrm{pH}$ of the sampled spring and tap water from Gikondo industrial area fall far from the safe standard range of $6.5-8.5 \mathrm{pH}$ recommended by WHO (WHO, 1998).

According to their respective recorded $\mathrm{pH}$ values, spring and tap water are not acceptable as water with low $\mathrm{pH}$ tends to make water corrosive. Continuous use and application of this water, especially in irrigation will render the soils unfit for further cultivation as most of our soils will be acidic. Hence the spring water and tap water distributed have low $\mathrm{pH}$ that hampers crop growth. According to (David et al., 1996), the optimum $\mathrm{pH}$ of irrigation water is in range from 6.5 to 8.5 . Therefore, river water would be good for irrigation. It is necessary that complete restraints should be observed for the application of either industrial park spring water or tap water distributed to the cultivable land. Treatment to adjust the $\mathrm{pH}$ of the three types of sample is essential before the use of any of the sampled water resources.

The values of the turbidity were recorded high for river water than spring and tap water; the turbidity values range from 42-92NTU, 8.99.1NTU and 12.3-14.1NTU respectively for river water, spring water and tap water (Table
The result of physical ( $\mathrm{pH}$ and turbidity) and chemical $\left(\mathrm{Cl}^{-}, \mathrm{SCN}^{-}, \mathrm{COD}, \mathrm{BOD}\right.$ and $\left.\mathrm{DO}\right)$ analysis from river water (industrial effluent), spring water and tap water are presented in the Table 1 according to different days of sampling.
1). Chloride content was also analyzed and found more in spring water than in any other sampled water: 7.1-10.5, 9.5-12.5 and 1.8-2.8 for tap water, spring water and river water respectively. Therefore, Gikondo industrial park water are most injurious to soil and plant health; wild life and hazardous for aquatic life without forgetting the human who used it for household purposes.

The qualitative analysis of thiocyanate $\left(\mathrm{SCN}^{-}\right)$in Table 1, revealed only the presence or absence of thiocyanate ion in small quantity. The analysis was positive, meaning that it appeared in the river water being industrial effluent as high dark blood red color (++++ to $+++++)$, for the spring water as a medium blood red color $(++$ to +++$)$ while in tap water it is shown as clear blood red color (+ to ++$)$.

As it is shown on Table 1, the dissolved oxygen values range from $0.90-0.98,1.9-2.3$ and 32-34 respectively for river water, spring water and tap water. There is a remarkable difference in chemical oxygen demand as the highest range was observed in tap water (11.5-13.9) and for the rest of sample it was ranging from 5.0 to 8.9 and 7.4 to 9.6 respectively for river and spring water.

The organic components in the river water sample were much higher than the permissible limit of $3 \mathrm{mg} / \mathrm{L}$ or less for BOD and 2mg/l or less for COD (APHA, 1998). Water containing high BOD and COD are responsible for a heavy depletion of oxygen levels in a particular section of streams 
or soils. Furthermore, if this water is mixed with public sewage and are used for irrigation, they will exert additional BOD and COD load on the sewage. The microorganisms present in the sewage will reduce the nitrate into nitrite and ammonia, sulphates into sulphides and ferric iron into ferrous iron at very low concentrations of oxygen. Therefore, they will constitute a great nuisance for the environment (Robson and Neal, 1997). The COD of the three sampled water, depicted in Table 1, shows that all samples had higher COD values than 2 $\mathrm{mg} / \mathrm{L}$ or less proposed by APHA (APHA, 1998). Therefore, these effluents need further elimination of COD through proper treatment methods before use (Babu, Nivas and Rajasekaran, 1992). The DO values of the sampled water as shown in Table 1, shows that all sampled water except tap water had lower DO value than the one of 4 $\mathrm{mg} / \mathrm{L}$ or more recommended by WHO (WHO, 2006). Therefore, these effluents need further addition of DO through proper treatment (Babu, Nivas and Rajasekaran, 1992).

Dissolved oxygen (DO) is of great significance to all living organisms. Concentration of DO is one of the most important parameters to indicate water quality in terms of purity (Bhatt, Lacoul, Lekhak and Jha, 1999).

Therefore, our study results also revealed that the effluent (liver water) in preset condition is not fit for discharge to land water, as it would be hazardous for human and aquatic life due to the high concentration of toxicants.

\section{Microbiological Analysis}

Results of microbiological assays of Klebsiella, Enterobacter, Staphylococcus and Escherichia coli in three sampled water are shown in Table 2 below.

\begin{tabular}{lllll}
\hline Type of Sample & $\begin{array}{c}\text { P/A of } \\
\text { Klebsiella } \text { sps }\end{array}$ & $\begin{array}{c}\text { P/A of } \\
\text { Enterobacter sps }\end{array}$ & $\begin{array}{c}\text { P/A of } \\
\text { Staphylococus } \\
\text { aureus }\end{array}$ & $\begin{array}{c}\text { P/A of } \\
\text { Escherichia coli }\end{array}$ \\
\hline River water & + & + & + & + \\
Spring water & - & - & - & - \\
Tap water & - & - & - & - \\
\hline
\end{tabular}

(+): P, presence (-): A, absence

The microbial positive results were confirmed by bubbles (Staphylococcus), pink-burgundy color (Klebsiella and Enterobacter) and dark pink color (Escherichia coli). The microbial analysis of the three sampled water reflect the presence of Klebsiella, Enterobacter, Staphylococus and E.coli in river water. These results shows that the Gikondo industrial effluent water (river water) does not fit for drinking for drinking purposes according to WHO recommendation (Parihar, Sharma and Sharma, 2003; Mohan, Gaur and Chodhary, 2007).

Staphylococcus aureus causes a variety of suppurative (pus-forming) infections and toxinoses in humans. It causes superficial skin lesions such as boils, styes and furuncules, more serious infections such as pneumonia, mastitis, phlebitis, meningitis, and urinary tract infections (Fujioka et al., 1999). Staphylococcus aureus causes food poisoning by releasing enterotoxins into food, and toxic shock syndrome by release of superantigens into the blood stream (Kenneth, 2008).

Total coliforms: Coliform organisms, are not an index of faecal pollution or of health risks, but can provide basic information on source of water quality. Traditionally, total coli forms were regarded as belonging to the genera

Escherichia, Citrobacter, Enterobacter, and Klebsiella (Fujioka et al., 1999). It includes many lactose fermenting bacteria, such as Enterobacter cloacae and Citrobacter freundii, which can be found in both faeces and the environment (nutrient-rich waters, soil) as well as in drinking water containing relatively high concentrations of nutrients (Allen, et al., 2000). Where it can be demonstrated that coliforms in water are not faecally derived and are, thus, of no sanitary significance, expenditure to achieve their eradication may be considered unnecessary and many standards require only absence of total coliforms from $95 \%$ of samples from within distribution systems (Clark, 1968). However, if used as an indicator of treatment efficiency, total coliform bacteria should not be detectable in water leaving a treatment works and in such cases their detection should provoke immediate investigation and corrective action.

E. coli is abundant in human and animal faeces, and in fresh faeces it may attain concentrations of 109 per gram. It has been suggested that E. coli may be present or even multiply in tropical water and is not subject to 
human faecal pollution (Fujioka et al., 1999). However, even in the most remote regions, faecal contamination by wild animals, including birds, can never be excluded.

\section{Conclusion and Recommendations}

Conclusively, the variations in the water quality parameters are evident in all the physicochemical parameters examined. The analysis indicates that the relative importance of water of industrial effluents is moderately hard with moderate turbidity, high BOD and COD level as in comparison to WHO standards.

The results of characterization of this water effluent show that the water has high pollution potentials and so need to be treated before disposal. However, biological method was not found to be suitable. Physicochemical treatment of the wastewater yielded good solid reduction after filtration, high BOD and COD reduction, high nitrate and phosphate reduction, thus preventing eutrophication due to the presence of these undesirable nutrients and also maximum bacterial death. The wastewater could therefore be discharged safely without the fear of pollution.

The effluents are moderately polluted. Such polluted effluents must be treated properly before their discharge into the drainage channel to minimize the effect of various pollutants on the environment.

Total coliform are detectable by simple, inexpensive cultural methods that require basic routine bacteriology laboratory facilities. $E$. coli is widely preferred as an index of faecal contamination. It is also widely used as an indicator of treatment of effectiveness, as with the other coliform indicators; it is more sensitive to disinfection than many pathogens (in particular viruses and protozoa). The detection of $E$. coli in water provides a treatment task for the same symptoms indicated by any other coliform organism, but its absence does not necessarily indicate that pathogens have been eliminated.

There is a wide range for types of microbial pathogen which can occur in wastewater, the type and number present are highly dependent on the socioeconomic conditions and customs of the communities creating the wastewater. In order to propose an efficient way of treating wastewater, there is need to understand the negative environmental impacts posed by the untreated or inadequately treated wastewater entering the nearby ecosystems, especially on the lives that depend on the ecosystem for sustenance.

\section{References}

Allen, M.J., Clancy, J.L. and Rice, E.W. (2000). Pathogen monitoring - old baggage from the last millennium. Journal of the American Water Works Association 92(9): 64-76.

American Public Health Associated (APHA). (1998). Standard method for examination of water and waste water, 20th Ed. American Public Health Associated Inc, New York: American Water Work Associated (AWWA).

Bhatt, L.R. Lacoul, H.D. Lekhak, H. and Jha, P.K. (1999). Physicochemical characteristics and phytoplankton of Taudaha lake, Kathmandu. Environmental Science and Pollution Research, 18(4): 353-358.

Clark, J.A. (1968). A presence-absence (PA) tests providing sensitive and inexpensive detection of coliforms, fecal coliforms and fecal streptococci in municipal drinking water supplies. Canadian Journal of Microbiology, 14 (1): 13-18.

David, H.F.L., Bela, G.L., Paul, A.B. (1996). Environmental Engineers Handbook. $2^{\text {nd }}$ Edition. New York: Lewis Publishers; pp. 43-49

Fujioka, R., Sian-Denton, C., Borja, M., Castro, J. and Morphew, K. (1999). Soil: the environmental source of Escherichia coli and Enterococci in Guam's streams. Journal of Applied Microbiology Symposium Suppl 85: 83S-89S.

Kenneth, T. (2008). Staphylococcus aureus and Staphylococcal Disease. Online text book of bacteriology. Available at: http://textbookofbacteriology.net/staph 2 . html, [Accessed on $6^{\text {th }}$ August, 2012].

Mark, J. Hammer, M.J. and Hammer, Jr. (1996). Water and Wastewater Technology, $3^{\text {rd }}$ edition. New Jersey: Printice Hall, Inc., Englewood. pp. 304316.

Mohan, D.G.A. and Chodhary, D. (2007). Study of limnology and microbiology of Naya Talab, Jodhpur, Rajasthan, Proceeding at Indian National Symposium on limnology.

Parihar, V.L. Sharma, M.S. and Sharma, L.L. (2003). Utility of bacteriological parameters for assessing best use and trophic status of seasonal water: A case study from Udaipur Rjasthan. Environmental Science and Pollution Research, 22(2): 163-167. 
Pelczar, M.J.R., Chan, E.C.S. and Krieg, N.R. (1986). Microbiology. $5^{\text {th }}$ Edition. New Delhi: Tata McGraw-Hill, pp. 568-592.

Perrin, R. and Scharff, J.P. (2002). Industrial Chemistry, $2^{\text {nd }}$ Edition. Paris: Dunod, $p p$ 12-18.

Robson, A.J. and Neal, C. (1997). Regional water quality of the Tweed. Science of the Total Environment, 194 (195):173192.

Sial, R.A., Chaudhary, M.F., Abbas, S.T. Latif, M.I. and Khan, A.G. 2006. Quality of effluents from Hattar Industrial Estate. Journal of Zhejiang University Science, 7(1), 974-980.
Skoog, D.A., West, D.M. and Holler, F.J. (1988). Fundamentals of Analytical Chemistry. $5^{\text {th }}$ Edition. New York: Saunders College Publishing, pp. 150-180.

Babu, S.C. Nivas, B.T. Rajasekaran, B. (1992). Ground water pollution through Agrochemicals-A dynamic model of externalities and policy options. Water Resources Management, 6(1): 1-13.

World Health Organisation (WHO), (1998). Guidelines for drinking water quality, Health criteria and other supporting information. Geneva: WHO.

World Health organization (WHO), (2006). Guidelines for drinking water quality. Geneva: WHO. 